RELATIONS OF GEOMORPHOLOGY TO STREAM HABITAT AND TROUT STANDING STOCK IN SMALL ROCKY MOUNTAIN STREAMS

R.P. Lanka, W.A. Hubert and T.A. Wesche

1987

Journal Article

WWRC - 87-24

In

Volume 116

Transactions of the American Fisheries Society

\author{
R.P. Lanka \\ W.A. Hubert \\ Wyoming Cooperative Fishery \& Wildlife Research Unit \\ University of Wyoming \\ Laramie, Wyoming
}

T.A. Wesche

Wyoming Water Research Center

University of Wyoming

Laramie, Wyoming 


\title{
Relations of Geomorphology to Stream Habitat and Trout Standing Stoch in Small Rocky Mountain Streams
}

\author{
Robert P. Lanka and Wayne A. Hubert \\ Wyoming Cooperative Fishery and Wildlife Research Unit,' University of Wyoming \\ Laramie, Wyoming 82071 , USA
}

ThOMAS A. WeSChE

Wyoming Water Research Center. University of W'yoming

\begin{abstract}
Evidence that drainage basin morphology and trout standing stock are related through a functional link between geomorphic features and stream habitat quality is presented. Numerous significant univariate correlations were found between geomorphic variables, stream habitat variables, and trout standing stock in both high-elevation forest and low-elevation rangeland streams. Canonical correlations between geomorphic variables and stream habilat variables provided insight into the form of the functional link. Multiple-regression equations predicting trout standing stock were dominated by geomorphic variabies. When geomorphic variables alone were incorporated into regression models they predicted trout standing stock as accurately as did stream habitat variables.
\end{abstract}

Methods for predicting standing stock of trout (species of Salmo and Salvelinus) in Rocky Mountain streams have focused mainly on stream habitat variables; little attention has been given to the possible influence of drainage basin geomorphology on stream habitat quality. Streams are known to reflect both the hydrology and biology of their watersheds (Platts 1979), but fish production dy also be related to geomorphic processes $i_{i}$, he drainage basin.

A few studies have attempted to relate geomorphic features of the watershed with salmonid standing stocks. Using geomorphic variables from Ziemer (1971) and Burton and Wesche (1974), Wesche et al. (1977) developed an index of habitat quality for cutthroat trout Salmo clarki in the Sierra Madre Range of Wyoming. Oswood and Barber (1982) combined measures of drainage basin geomorphology and stream habitat to predict salmonid standing stock in Alaskan streams, whereas Parsons et al. (1981) developed models incorporating geomorphic variables for salmonid streams in Oregon. However, these studies have not investigated the relation between geomorphic variables and stream habitat variables, nor have they examined the contribution of each type of variable when predicting salmonid standing stock in streams.

We demonstrate that measures of drainage ba-

\footnotetext{
'The unit is jointly supported by the University of Wyoming, Wyoming Game and Fish Department, and United States Fish and Wildlife Service.
}

sin geomorphology are related to both stream habitat features and trout standing stock. We also describe the ability of geomorphic and stream habitat variables to predict trout standing stock independently and in combination with each other.

\section{Methods}

Data were compiled for streams in the Colorado and Missouri river drainages within Wyoming from two sources: file data from the U.S. Bureau of Land Management and the University of Wyoming, and data gathered in the field during summer 1984. File data were accepted if three conditions were met: (1) stream habitat data and standing stock estimates were collected over the same reach within 1 month of each other; (2) a channel-stability evaluation had been conducted (Pfankuch 1975), and nine stream habitat variables measured (Table 1); and (3) a minimum twopass depletion estimate of fish abundance had been made by the DeLury (1951) or Zippin (1958) methods.

Stream habitat variables. - In June, July, and August 1984 , data were collected on small perennial streams ( $<10 \mathrm{~m}$ average wetted width during summer low-llow) known to support trout. At least one pool-rille sequence typical of the stream was included in each $75-\mathrm{m}$ study reach. Within each reach, 10 cross-channel transects were established at $7.5-\mathrm{m}$ intervals. Wetted stream width was measured perpendicular to flow at each transect and mean welled stream width was then computed for the reach. Depth measurements were taken at 
TABLE 1.- Range of measured values for stream reaches assessed in Wyoming.

\begin{tabular}{|c|c|c|}
\hline Variable & Forest streams $(N=65)$ & Rangeland streams $(N=26)$ \\
\hline Trout standing crop (kg/hectare) & $1.0-604.2$ & $8.5-393.9$ \\
\hline \multicolumn{3}{|l|}{ Stream measurements } \\
\hline Channel stability score & $51-|4|$ & $61-128$ \\
\hline Average wetled reach width $(m)$ & $0.78-9.14$ & $1.52-7.47$ \\
\hline Average reach depth $(\mathrm{m})$ & $0.04-10.40$ & $0.50-0.46$ \\
\hline Average reach velocity $(\mathrm{m} / \mathrm{s})$ & $0.06-0.81$ & $0.07-0.74$ \\
\hline Width : depth ratio & $5.0-88.83$ & $6.63-48.80$ \\
\hline Bedrock-boulder substrate $(\%)$ & $0-74$ & $0-53$ \\
\hline Rubble substrate $(\%)$ & $0-70$ & $0-67$ \\
\hline Gravel substrate $(\%)$ & $0-70$ & $3-56$ \\
\hline Silt-sand substraic $(\%)$ & $0-46$ & $6-77$ \\
\hline Reach gradient $(\%)$ & $1-9$ & $1-4$ \\
\hline \multicolumn{3}{|l|}{ Geomorphic measurements } \\
\hline Reach elevation $(m)$ & $2.097-3.158$ & $1.329-2.245$ \\
\hline Midrange basin elevation $(\mathrm{m})$ & $2.426-3.362$ & $1,987-2.841$ \\
\hline Stream order & $1-5$ & $2-6$ \\
\hline Basin area (hectare) & $95-39.290$ & $1,348-48.918$ \\
\hline Basin perimeter (ha) & $5-96$ & $23-173$ \\
\hline Basin relief $(\mathrm{m})$ & $165-1.601$ & $267-3.024$ \\
\hline Compactness coefficient ${ }^{b}$ & $0.08-0.36$ & $0.14-0.26$ \\
\hline Stream length $(\mathrm{km})$ & $1.7-29.3$ & $8.3-72.4$ \\
\hline Relief ratio $(\mathrm{m} / \mathrm{km})$ & $23.5-262.3$ & $14.8-116.3$ \\
\hline Channel slope $(\mathrm{m} / \mathrm{km})$ & $8.4-116.1$ & $10.1-70.0$ \\
\hline Drainage density $\left(\mathrm{km} / \mathrm{km}^{2}\right)$ & $0.40-4.2$ & $0.8-5.5$ \\
\hline
\end{tabular}

a Low values indicate stability. high values erosive conditions

b Basin perimeter/2(3.14 basin area $)^{1 / 2}$.

points that were $0.25,0.50$, and 0.75 of the wetted stream width; the three depth measurements for each transect were summed and divided by four to compute mean transect depth. Platts et al. (1983) found this method of computing mean depth to have a $95 \%$ confidence interval about the mean of $\pm 8.2 \%$. The mean depth for each of the 10 transects was averaged to obtain mean depth of the reach. Width : depth ratio was computed as the mean wetted width divided by the mean reach depth. At each point where depth was measured. the dominant substrate class was visually determined as either silt-sand ( $\leq 0.25 \mathrm{~cm}$ diameter). gravel $(0.26-7.5 \mathrm{~cm})$, rubble $(7.6-30.0 \mathrm{~cm})$, or bedrock-boulder $(\geq 30.1 \mathrm{~cm})$. The number of points at which each substrate class was found. divided by the total number of measurements. gave the proportion of each substrate class in the reach.

To estimate surface water velocity, we floated a pencil three times over a relatively straight. unobstructed subsection of the reach for about 20 s. Distance traveic. and float duration were re- . corded. The mean subsection velocity $(\mathrm{m} / \mathrm{s})$ was computed and multiplied by 0.85 to adjust for above-average water velocity at the surface. Within this subsection. three equally spaced transects were established to determine average subsection width and depth. Stream discharge $\left(\mathrm{m}^{3} / \mathrm{s}\right)$ was cal- culated as the mean cross-sectional area of the reach subsection multiplied by mean velocity in the subscction. For an assumed constant discharge through the reach. mean reach velocity was computed as the discharge divided by the mean crosssectional area of the 10 reach transects. Reach gradient was estimated with a clinometer.

Channel stability was visually estimated following Pfankuch (1975). Fifteen stability indicators were rated numerically over an entire stream reach and summed to yield a reach score used in our data analyses. The score reflects the channel stability, with a low value indicative of a stable channel and a high score indicative of an erosive channel.

Geomorphic variables. - Eleven geomorphic variables were measured on 1:24,000 or, when not available. 1:62,500 scale topographic maps of the U.S. Geological Survey (Reston. Virginia) (Table 1). Each study reach was located on a topographic map and its drainage divide was drawn. Variables were measured as follows:

(1) Study reach elevation: read directly from the map.

(2) Midrange basin elevation: (highest elevation on the headwater divide + reach elevation) $/ 2$. 
(3) Stream order: determined by counting the stream channels shown in blue on topographic maps (Horton 1945, as modified by Strahler 1957).

(4) Basin area: measured with a compensating polar planimeter (Horton 1945).

(5) Basin perimeter: measured with a map measurer (Horton 1945).

(6) Basin relief: highest elevation on the headwater divide minus the elevation of the reach (Schumm 1956).

(7) Compactness coefficient: basin perimeter/ 2(3.14 basin area) $)^{1 / 2}$ (Parsons et al. 1981).

(8) Stream length: measured by following the longest watercourse shown in blue on the map with a map measurer (Horton 1945).

(9) Relief ratio: basin relief/stream length (Schumm 1956).

(10) Channel slope: (elevation at $85 \%$ of stream length - elevation at $10 \%$ of stream length)/ stream length between these two points (Craig and Rankl 1978)

(11) Drainage density: length $(\mathrm{km})$ of all stream channels shown in blue in a drainage basin/ drainage area $\left(\mathrm{km}^{3}\right)$ (Horton 1945).

Standing stock estimates. - Estimates of trout (brown trout Salmo trutta, rainbow trout $S$. gairdneri, brook trout Salvelinus fontinalis, and cutthroat trout) standing stock in each reach were made by the removal method (DeLury 1951). Each reach was blocked at the upper and lower ends with minnow seines and two or three depletion passes were made with a battery-powered backpack electroshocker. At the end of each pass, fish were weighed to the nearest gram and natural total length was measured to the nearest millimeter. Only data from trout $100 \mathrm{~mm}$ or longer were recorded. Estimates of trout abundance in each reach were computed with program CAPTURE (White et al. 1982). Model $\mathrm{M}(\mathrm{bh})$ was chosen because it allowed for variability in capture among animals and for behavioral responses to the first capture attempt.

Data analysis. - High-elevatiun coniferous forest watersheds were separated from lower-elevation rangeland watersheds. The boundary elevation between forest and rangeland streams approximately followed the low-elevation coniferous forest timberline in Wyoming: $2,287 \mathrm{~m}$ at $41^{\circ}-11^{\circ} 60^{\prime} \mathrm{N}$ latitude: $2,135 \mathrm{~m}$ at $42^{\circ}-42^{\circ} 60^{\prime} ; 1,982$ $\mathrm{m}$ at $43^{\circ}-43^{\circ} 60^{\prime}$; and $1,830 \mathrm{~m}$ at $44^{\circ}-44^{\circ} 60^{\prime}$.

For statistical analyses, we used BMDP (Dixon et al. 1981) and the Statistical Package for the
TABLE 2. - Coefficients of correlation $(r)$ between stream habitat or geomorphic variables and trout standing stock in Wyoming streams. Coefficients are shown only if they are signiticant at $P \leq 0.10$.

\begin{tabular}{|c|c|c|}
\hline Variable & $\begin{array}{l}\text { Forest } \\
\text { streams } \\
(N=65)\end{array}$ & $\begin{array}{c}\text { Rangeland } \\
\text { streams } \\
(N=26)\end{array}$ \\
\hline \multicolumn{3}{|l|}{ Stream measurements } \\
\hline $\begin{array}{l}\text { Average reach width } \\
\text { Average reach velocity }\end{array}$ & $-0.42^{3}$ & $\begin{array}{l}-0.52^{\mathrm{a}} \\
-0.52^{\mathrm{a}}\end{array}$ \\
\hline Width: depth ratio & -0.46 & -0.48 \\
\hline Rubhle substrate & -0.24 & -0.48 \\
\hline Gravel substrate & 0.22 & \\
\hline Silt-sand substrate & & 0.37 \\
\hline Reach gradient & $\therefore-0.17$ & \\
\hline \multicolumn{3}{|l|}{ (siomorphic measurements } \\
\hline Reach clevation & $-0.20^{\mathrm{a}}$ & 0.52 \\
\hline Midrange basin elevation & $-0.41^{2}$ & \\
\hline Stream order & & $-0.57^{3}$ \\
\hline Basin area: & & -0.28 \\
\hline Basin relief & $-0.37 \mathrm{a}$ & $-0.66^{2}$ \\
\hline Relief ratio & $-0.35^{\mathrm{a}}$ & $-0.40^{3}$ \\
\hline Channel slope $i$ & & -0.37 \\
\hline Drainage density & -0.22 & \\
\hline
\end{tabular}

a Based on a $\log _{10}$ transformation of the independent variable

Social Sciences (SPSS; Nie et al. 1975). Correlation analysis was used to determine the correlation (and its significance) between each independent variable and trout standing stock, as well as relations between geomorphic and stream habitat variables.

The relations between those geomorphic and stream habitat variables that were significantly correlated $(P \leq 0,10)$ to trout standing stock were investigated further by canonical correlation. If a pair of stream habitat or a pair of geomorphic variables were highly multicolinear $(R \geq 0.75)$, one of the two was excluded from analysis to eliminate redundant variables. The remaining variables were used to generate a canonical model for both forest and rangeland streams. Canonical correlation coefficients $\left(R_{c}\right)$ were computed such that the linear combination of stream habitat variables (variate $u$ ) was maximally correlated to the linear combination of geomorphic variables (variate $v$ ). Canonical models enable the investigation of more than one relation between the variable sets because they are generated independently (Levine 1977).

Normal probability plots and standardized residual plots were inspected to detect violations of regression assumptions and to determine if logarithmic transformations of certain independent variables were valid (Zar 1974). If logarithmic transtormations increased the variance accounted 
TABLE 3. - Correlation coefficients between stream habitat and geomorphic variables that were significantly correiated with trout standing stock.

\begin{tabular}{|c|c|c|c|c|c|c|c|c|c|c|}
\hline \multirow[b]{2}{*}{$\begin{array}{l}\text { Stream habitat } \\
\text { variables }\end{array}$} & \multicolumn{10}{|c|}{ Geomorphic variables } \\
\hline & $\begin{array}{l}\text { Reach } \\
\text { cleva- } \\
\text { ation }\end{array}$ & $\begin{array}{c}\text { Mid- } \\
\text { range } \\
\text { basin } \\
\text { cleva- } \\
\text { tion }\end{array}$ & $\begin{array}{l}\text { Basin } \\
\text { relicf }\end{array}$ & $\begin{array}{l}\text { Relicf } \\
\text { ratio }\end{array}$ & $\begin{array}{l}\text { Drainage } \\
\text { density }\end{array}$ & $\begin{array}{l}\text { Stream } \\
\text { length }\end{array}$ & $\begin{array}{c}\text { Strcam } \\
\text { order }\end{array}$ & $\begin{array}{l}\text { Basin } \\
\text { area }\end{array}$ & $\begin{array}{l}\text { Basin } \\
\text { perim- } \\
\text { eter }\end{array}$ & $\begin{array}{c}\text { Channel } \\
\text { slope }\end{array}$ \\
\hline \multicolumn{11}{|c|}{ Forest streams (critical $r=0.21: N=65: P \leq 0.10$ ) } \\
\hline Average reach width & & 0.36 & 0.56 & & -10.28 & & & & & \\
\hline Rubble substrate & 0.29 & 0.43 & 0.28 & & -0.22 & & & & & \\
\hline Gravel substrate & -0.47 & -0.45 & & 0.28 & & & & & & \\
\hline Reach gradient & & & & & 0.54 & & & & & \\
\hline Width : depth ratio & 0.41 & 0.44 & & & 0.28 & & & & & \\
\hline \multicolumn{11}{|c|}{$\chi$ Rangeland streamş,critical $r=0.33 ; N=26 . P \leq 0.10)$} \\
\hline Average reach width & -0.67 & & 0.62 & & & 0.63 & 0.62 & 0.60 & 0.55 & \\
\hline Average reach velocity & -0.60 & & 0.56 & & & 0.52 & 0.71 & 0.55 & 0.46 & \\
\hline Rubble substrate & -0.44 & & 0.53 & 0.46 & & & 0.50 & & & 0.58 \\
\hline Silt-sand substrate & & & 0.35 & & & -0.48 & & -0.44 & -0.48 & \\
\hline Width: depth ratio & -0.50 & & & & & & 0.33 & & & \\
\hline & $x$ & & $n$ & & & $\lambda$ & $x$ & $x$ & $x$ & \\
\hline
\end{tabular}

for by at least $5 \%$, the transformed variable was chosen over the untransformed one for inclusion in multiple-regression analyses.

Variables significantly correlated $(P \leq 0.10)$ with trout standing stock were analyzed further for their combined influences on trout standing stock by means of BMDP all-subsets, multiple lincar regression (Dixon et al. 1981). This program was used to generate a series of regression models. Each model was then evaluated to determine if the variables included in the model related to trout standing stock in a way that was consistent with results of other studies and current biological thought. After "nonsense" models were cxcluded. the model with the highest adjusted coefficient of determination. $R_{a}{ }^{2}$, was chosen (Neter and Wasscrman 1974). When the models were tested against an independent data set. prediction error was computed as the difference between predicted and actual standing stock divided by the predicted value and expressed as a percentage.

\section{Results}

Data from a total of 91 stream reaches were analyzed. 38 from file information and 53 from our own sampling; 65 were in forests and 26 in rangelands. Many of the variables analyzed in both forest and rangeland streams were significantly $(P \leq 0.10)$ correlated with trout standing stock. In forest streams, five of the 10 stream variables and five of the 11 geomorphic variables were significantly correlated with trout standing stock ( $\mathrm{Ta}$ - blc 2): in rangeland streams, five of the 10 stream variables and six of the 11 geomorphic variables were significantly correlated with trout standing stock.

Upon inspection of plots of each independent variable and trout standing stock, three independent variables suggested a curvilinear relation with standing stock. These three variables were rated from 1 (low standing-stock range) to 3 (high standing-stock range) to yield a more linear relation between the rated predictor variable and trout standing stock:

$$
\begin{aligned}
& \text { reach clevation ( } R E \text { ), } \\
& 1=R E<2.150 \mathrm{~m} \text {, } \\
& 2=\mathrm{RE}>2.355 \mathrm{~m} \text {, } \\
& 3=2.150 \leq R E \leq 2.355 \mathrm{~m} \text { : } \\
& \text { midrange basin elevation (MRE). } \\
& 1=\mathrm{MRE} \leq 2.000 \mathrm{~m} \text { or } \\
& M R E \geq 2.600 \mathrm{~m} \text {, } \\
& 2=2.000<\mathrm{MRE}<2,325 \mathrm{~m} \text { or } \\
& 2,475<M R E<2,600 \mathrm{~m} \text {, } \\
& 3=2.325 \leq M R E \leq 2,475 \mathrm{~m} \text {; } \\
& \text { width : depth ratio (WD), } \\
& 1=W D \leq 10 \text { or } W D \geq 33 \text {, } \\
& 2=23 \leq W D \leq 32 \text {, } \\
& 3=11 \leq W D \leq 22 \text {. }
\end{aligned}
$$

Analysis demonstrated a significant relation between trout standing stock and rated reach elevation $\left(r_{a}{ }^{2}=0.25\right)$ in forest streams and between midrange basin elevation $\left(r_{a}{ }^{2}=0.40\right)$ and width : depth ratio $\left(r_{\alpha}{ }^{2}=0.45\right)$ in rangeland streams. 

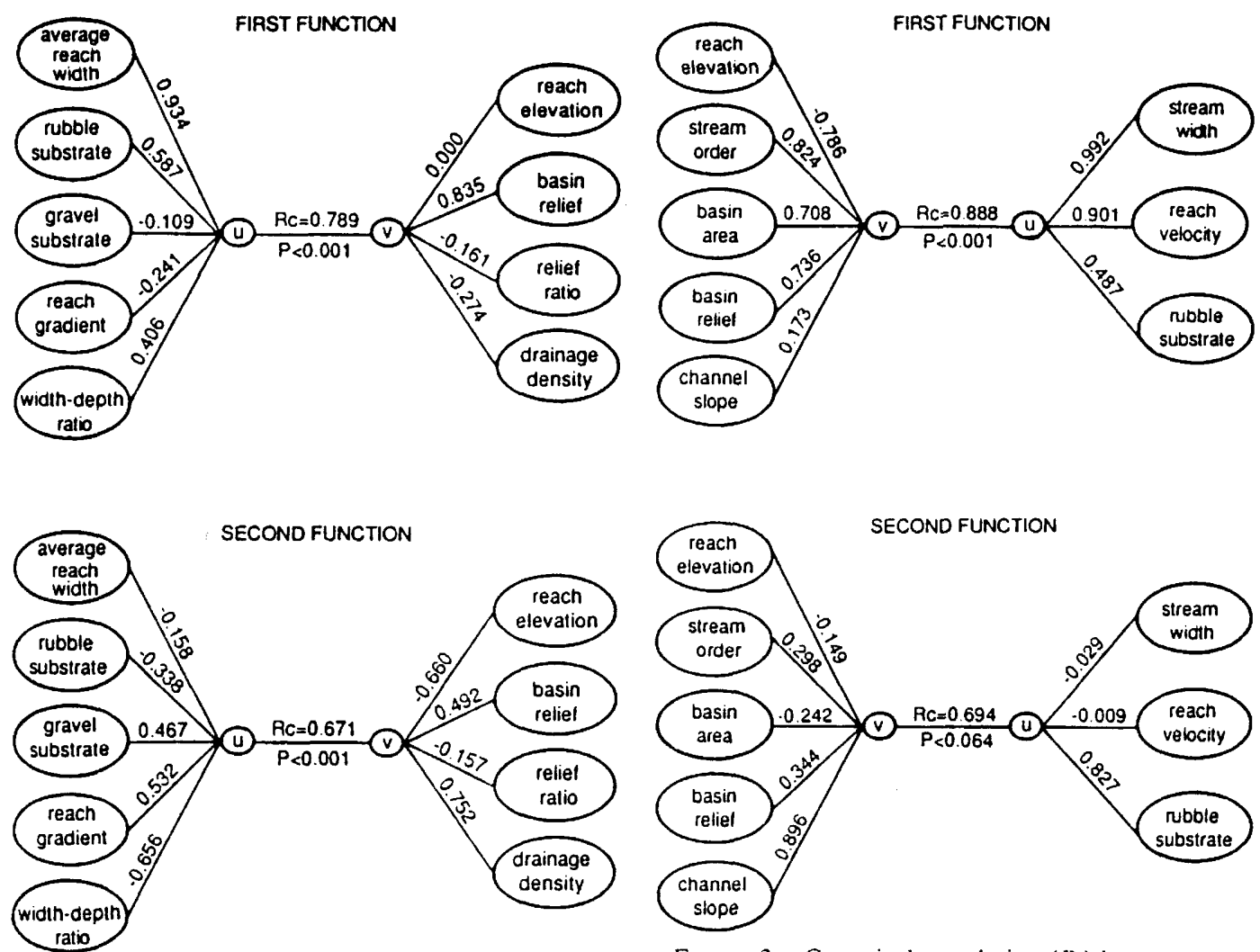

Figure 1.-Canonical correlation $\left(R_{\text {. }}\right)$ between measures of stream habitat (canonical variate $u$ ) and drainage basin geomorphology (canonical variate $v$ ) in forest streams.

Relations between Stream Habitat and Geomorphic Variables

Stream habitat and geomorphic variables significantly correlated with trout standing stock were analyzed further to determine their relations with each other. For forest streams, 14 statistically significant correlations exited between the live stream habitat variables and the five geomorphic variables (Table 3). Each of the geomorphic variables correlated significantly with one to four stream habitat variables. In rangeland streams, 23 statis tically significant correlations were observed between the five stream habitat variables and the eight geomorphic variables (Table 3 ).

Canonical analysis indicated significant correlations between the stream habitat variate and geomorphic variate. In forest streams the canonical correlation (Figure 1) between the canonical variates for the first function was highly signiticant $\left(R_{t}=0.79 ; P \leq 0.001\right)$. Canonical variale $v$ re-

FlialRE 2.-Canonical correlation $(R)$ between measures of stream habitat (canonical variate $u$ ) and drainage basin geomorphology (canonical variate $v$ ) in rangeland strcams.

flected drainage basin size whereas canonical variate $u$ reflected stream size. The second function also was highly significant $\left(R_{i}=0.67 ; P \leq 0.001\right)$. Canonical variate $y$ reflected drainage basin features that indicated decreased discharge response time to rainfall events, and canonical variate $u$ reflected stream channel adjustments to this decreased response time.

A signiticant relation between the canonical variates for the first function also was found in rangeland streams $\left(R_{\mathrm{c}}=0.89 ; P \leq 0.001\right.$; Figure 2). Again, canonical variate $v$ reflected drainage basin size and canonical variate $u$ reflected stream size. The second function was also significant $\left(R_{i}=\right.$ $0.69 ; P=0.064)$. Canonical variate $v$ reflected basin gradient, and canonical variate $u$ may have rellected food-producing areas and instream cover.

\section{Regression Models}

Three multiple-regression equations describing trout standing stock as kilograms/hectare $(Y)$ were 
TABLE 4.-Correlation coefficients and mean prediction errors for tests of models relating trout standing stock in Wyoming streams to stream habitat and geomorphic variables.

\begin{tabular}{|c|c|c|c|}
\hline Statistic & $\begin{array}{l}\text { Com- } \\
\text { bined } \\
\text { model }\end{array}$ & $\begin{array}{l}\text { Stream } \\
\text { model }\end{array}$ & $\begin{array}{l}\text { rieomor- } \\
\text { phic } \\
\text { moddel }\end{array}$ \\
\hline \multicolumn{4}{|c|}{ Forest $(N=11)$} \\
\hline Correlation coefficient $(r)$ & 0.80 & $0.32^{\mathrm{a}}$ & 0.75 \\
\hline Prediction error $(\%)$ & 73 & 103 & 101 \\
\hline \multicolumn{4}{|c|}{ Rangeland $(N=8)$} \\
\hline Corrclation coefficient $(r)$ & 0.96 & 0.90 & 0.69 \\
\hline Prediction error $(\%)$ & 18 & 29 & 50 \\
\hline
\end{tabular}

developed for both forest $(N=65)$ and rangeland $(N=26)$ streams. In one model (combincd model), both geomorphic and stream habitat variables were used (Table 3); the second and third models incorporated only stream habitat or geomorphic variables, respectively. Geomorphic variables dominated the combined models for both forest and rangeland streams: three of the four independent variables were geomorphic measures. Similar relations were observed between stream habitat models and geomorphic models for both forest and rangeland streams. but different independent variables were incorporated.

Forest stream models variously included three stream and four geomorphic variables: average reach width $(A R W)$, width : depth ratio ( $H D)$, and gradient $(G)$, and rated reach elevation $(R R E)$, relief ratio $(R R)$. drainage density (DD), and basin relief $(B R)$.

$$
\begin{aligned}
& \text { Combined variables: s7e0 } \\
& \begin{array}{c}
Y=447.8+67.5 R R E-153.7 \log _{10}(R R+1) \\
-35.7 D D-263.1 \log _{10}(A R W+1) \\
R_{a}{ }^{2}=0.51: P \leq 0.001 . \quad \text { Wilt }
\end{array}
\end{aligned}
$$

Stream variables:

$$
\begin{aligned}
Y= & 408.2-189.7 \log _{10}(A R I V+1) \\
& -113.9 \log _{10}(W D+1)-12.4 G \\
& R_{a}^{2}=0.31 ; P \leq 0.001
\end{aligned}
$$

Geomorphic variables:

$$
\begin{aligned}
Y= & 471.5+99.4 R R E-138.2 \log _{10}(B R+1) \\
& -123.6 \log _{10}(R R+1) \\
& R_{\mathrm{a}}{ }^{2}=0.36 ; P \leq 0.001 .
\end{aligned}
$$

Rangeland stream models included two stream and four geomorphic variables: rated width: depth ratio $(R W S)$ and average reach velocity $(A R V)$ and rated midrange basin elevation $(R M R E)$, basin perimeter $(B P)$, channel slope $(C S)$, and basin relicf $(B R)$.

$$
\begin{aligned}
& \text { Combined variables: }, \quad \mid \mathrm{er}^{\mathrm{N}} \\
& Y=200.3+36.1 R M R E-0.85 B P \\
& -138.7 \log _{11}(C S+1)+50.5 R W D \text {; } \\
& R_{n}^{2}=0.64 ; P \leq 0.001 \text {. }
\end{aligned}
$$

Geomorphic variables:

$$
\begin{aligned}
Y= & 487.6+53.3 R M R E \quad \text { Dain klif } \\
& -160.1 \log _{10}(B R+1) ; \\
& R_{\mathrm{a}}{ }^{2}=0.52 ; P \leq 0.001 .
\end{aligned}
$$

Following development of the regression equations, an independent data set was obtained from Wyoming Game and Fish Department and Wyoming Water Research Center records to test each model. In all models except the forest stream model. a significant correlation between model predictions and actual standing stock was obtained (Table 4). Rangeland stream tests yielded higher correlations and lower prediction errors than those associated with forest streams when computations followed Binns and Eiserman (1979). The combined model for each stream type gave the best test results.

\section{Discussion}

Relations between measures of drainage basin gcomorphology, stream habitat quality, and trout standing stock were demonstrated in this study by the numerous univariate correlations between geomorphic and stream habitat variables, the high canonical correlations between geomorphic variates and stream habitat variates. and the extent to which geomorphic variables accounted for variance in the standing stock of trout. Platts (1979) and Parsons et al. (1981) also looked at the relations between drainage basin geomorphology and stream habitat. Platts (1979) found that as stream orcier increased, stream width, depth, and the percent of rubble substrate also increased, whereas the percent of pool habitats, channel gradient, and the percent of gravel substrate decreased. Parsons et al. (1981) correlated a habitat condition score generated from measured features of stream habitat to four measures of drainage basin geomorphology. All of these relations combine to provide substantial evidence that stream habitat is a func- 
tion of geologic processes within the drainage ba$\sin$.

Geomorphic variables dominated (three of four variables) our multiple-regression models where both variable types were incorporated. In addition, when used separately, trout standing stock. was predicted as accurately with geomorphic variables as it was with stream habitat variables. Other studies have successfully used measures of drainage basin geomorphology to predict salmonid standing stock or abundance in streams (Ziemer 1971; Burton and Wesche 1974; Swanston et al. 1977). These observations suggest that geomorphic variables are useful in predicting the potential habitat quality of trout streams.

Our data confirm that small, gently sloping drainage basins produce the best trout habitat. Basin relief, relief ratio, and gradient indicate (by their negative relation to trout standing stock) that a large drop in elevation over the drainage basin leads to reduced trout habitat quality. Branson et al. (1981) stated that high basin relief resulted in greater channel slope and increased drainage density, both of which were negatively related to trout standing stock in our study. The combined effect of watershed features, such as increased basin slope (basin relief and relief ratio) increased channel shope (gradient), and a more dendritic drainage pattern (drainage density), may tend to decrease response Ume of suream discharge to rainfall events. Drainage basins with thesecharacteristics, when subjected to high-intensity. thunderstorms (which are common in Wyoming), generally have greater flow variability, decreased storage of water in depressions and as groundwater, and lower base flows (Yiessman et al. 1977). Low base flows and high flow variability result in poor habitat quality for troul (Binns and Eiserman 1970. Wascheet al., in press).

Highest trout biomass was associated with the transition zone between forest and rangeland stream types, which occurred between elevations of 2,100 and $2,355 \mathrm{~m}$ in forest streams and 2,100 and $2,224 \mathrm{~m}$ in rangeland streams. Platts (1979) found a similar situation in Idaho, and Elser (1968) observed the best habitat quality at the transition between high-gradient, boulder-substrate habitat (characteristic of forest streams) and lower-gradient, gravel-substrate habitat (characteristic of rangeland streams).

Increasing stream size, as reflected by geomorphic variables, resulted in reduced trout density in our study. This relation may be the result of a decrease in relative abundance of riparian cover or an increase in human impact with increasing stream size. Data presented by Conder (1982) indicated that as stream order increased in the Bighorn Basin of Wyoming human impact on the aquatic and riparian resources increased.

Statistical evidence leads us to the conclusion that the relation between drainage basin geomorphology and trout standing stock is the result of a functional link between measurable features of a drainage basin and stream habitat. This linkage may enable the use of simple measures of drainage basin geomorphology to predict potential habitat quality for trout.

\section{Acknowledgments}

We thank Michael Parker and Stephen Bieber for assistance in manuscript development; Fred Stabler and other Bureau of Land Management stalf in Wyoming for assistance in the tield and tile data collection; Wyoming Game and Fish Department biologists in Cheyenne, Laramie, Green River, Casper, Lander, and Buffalo for held assistance; and several Wyoming Water Research Center employees for their help. Additional appreciation is extended to members of the field crews: Eric Featherston, Carrie Frye, Gregory Melka, Barry Deibert, Randall Blake, and Phillip Hubert. Funding was provided by the U.S. Department of the Interior, U.S. Bureau of Land Management, and the Wyoming Water Research Center.

\section{References}

Binns, N. A., and F. M. Eiserman. 1979. Quantification of lluvial trout habitat in Wyoming. Transactions of the American Fisheries Society 108:215228.

Branson, F. A., G. F. Gifford, K. G. Rendard, and R. F. Hadley, 1981. Rangeland hydrology. Society for Range Management, Range Science Series 1, Denver, Colorado.

Burton. R. A., and T. A. Wesche. 1974. Relationship of duration of flows and selected watershed parameters to the standing stock estimates of trout populations. University of Wyoming, Water Resources Research Institute, Water Resouries Series 52, Laramie.

Conder, A. L. 1982. Instream How investigations on selected streams: Wyoming. Completion Report (Contract YA-512-CT9-226) to the Bureau of Land Management, Denver, Colorado.

Craig, G. S.. Jr., and J. G. Rankl. 1978. Analysis of runoff from small drainage basins in Wyoming. U.S. Geological Survey Water, Supply-Paper 2056.

DeLury O. B. 1951. On the planning of experiments for istimation of fish populations. Journal of the : isheries Research Board of Canada 8:281-307. Dixon, W. J., and six coauthors. 1981. BMDP statis- 
tical software. University of California Press, Berkeley.

Elser, A. A. 1968. Fish populations of a trout stream in relation to major habitat zones and channel alterations. Transactions of the American Fisheries Society 97:389-397.

Horton, R. E. 1945. Erosional development of streams and their drainage basins, hydrophysical approach to quantitative morphology. Geological Socicty of America Bulletin 56:275-370.

Levine. M. S. 1977. Canonical analysis and factor comparison. Quantitative applications in the social sciences. Sage. Beverly Hills. California.

Neter, J., and W. Wasserman. 1974. Applied linear statistical models. R. D. Irwin, Homewood. Illinois.

Nie. N. H., C. H. Hull, J. G. Jenkins, K. Steinbrenner. and D. H. Best. 1975. SPSS (Statistical package for the social sciences), 2nd edition. McGraw-Hill. New York.

Oswood. M. E., and W. E. Barber. 1982. Assessment of fish habitat in streams: goals. constraints. and a new technique. Fisheries (Bethesda) 7(4):8-11.

Parsons, M. G.. J. R. Maxwell, and D. Heller. 1981. A predictive fish habitat index model using geomorphic parameters. Pages 85-91 in N. B. Armantrout. editor. Acquisition and utilization of aquatic habitat inventory information. American Fisheries Socicty. Western Division, Bethesda, Maryland.

Pfankuch. D. J. 1975. Stream reach inventory and channel stability evaluation. U.S. Forest Service. Northern Region, Missoula. Montana.

Platts. W. S. 1979. Relationships among stream order, fish populations. and aquatic gcomorphology in an Idaho river drainage. Fisheries (Bethesda) 4(2):5-9.

Platts, W. S.. W. F. Megahan. and G. W. Minshali. 1983 Methods for evaluating stream. riparian, and biotic conditions. U.S. Forest Service General Technical Report INT-138.

Schumm. S. A. 1956. Evolution of drainage systems and slopes in badlands at Perth Amboy. New Jer- sey. Geological Society of America Bulletin 67:597646.

Strahler. A. N. 1957. Quantitative analysis of watershed geomorphology. Transactions, American Geophysical Union 38:913-920.

Swanston. D. N., W. R. Mechan, and J. A. McNutt. 1977. A quantitative geomorphic approach to predicting productivity of pink and chum salmon streams in southeast Alaska. U.S. Forest Service Rescarch Paper PNW-227.

Viessman, W., Jr., J. W. Knapp, G. L. Lewis. and T. E. Harbaugh. 1977. Introduction to hydrology. Harper and Row, New York.

Wesche, T. A.. C. M. Goertler, and W. A. Hubert. In press. A modified brown trout habitat suitability index (HSI) model for southeastern Wyoming. North American Journal of Fisheries Management 7.

Wesche, T. A.. D. W. Reiser, W. F. Wickers, and D. L. Wickers. 1977. Fishery resources and instream flow recommendations for streams to be impacted by Cheyenne's proposed stage II development. Completion Report to Wyoming Game and Fish Department, Cheyenne.

White G. C., D. R. Anderson, K. P. Burnham, and D. L. Otis. 1982. Capture-recapture and removal methods for sampling closed populations. Los Alamos National Laboratory, LA-8787-NERP. Los Alamos. New Mexico.

Zar, J. H. 1974. Biostatistical analysis. Prentice-Hall, Englewood Clifts. New Jersey.

Ziemer, G. L. 1971. Quantitative geomorphology of drainage hasins related to fish production. Alaska Department of Fish and Game. Information Leaflet 162. Juncau.

Zippin. C. 1958. The removal method of population estimation. Journal of Wildlife Management 22:8290.

Received March 12, 1986 Accepted February 6, 1987 